EXTENDED REPORT

\title{
Human ganglion cells express the alpha-2 adrenergic receptor: relevance to neuroprotection
}

\author{
F B Kalapesi, M T Coroneo, M A Hill
}

Br J Ophthalmol 2005;89:758-763. doi: 10.1136/bjo.2004.053025

See end of article for authors' affiliations

.....................

Correspondence to: Dr Mark Hill, Department of Anatomy, University of New South Wales, Sydney NSW 2052, Australia; m.hill@unsw.edu.au

Accepted for publication 1 October 2004

\begin{abstract}
Background/aim: Alpha- $2 \alpha$ adrenergic receptor $\left(\alpha_{2}\right.$-AR) agonists are thought to be neuroprotective, preventing retinal ganglion cell death independent of pressure reduction. Previous studies have identified $\alpha_{2}$-ARs in rat retina. The authors aimed to demonstrate the presence and localisation of $\alpha_{2}$-ARs in human and rat retina and on the rat retinal ganglion cell line, RGC-5.

Methods: Seven postmortem human and three postmortem rat eyes were paraformaldehyde fixed and frozen. RGC-5 cells were also paraformaldehyde fixed. The expression of $\alpha_{2 A}$-ARs was determined by antibody immunofluorescence.

Results: $\alpha_{2 A}-A R$ expression was identified in the human retina, on ganglion cells, and cells in the inner and outer nuclear layers (INL, ONL). Differential $\alpha_{2 A}-A R$ staining patterns in the INL and ONL suggest a further restriction to as yet unidentified neuronal subclasses. The RGC-5 cell line also expressed $\alpha_{2 A}$-ARs in undifferentiated cells and an increased expression upon fully differentiated cells.

Conclusion: $\alpha_{2}$-AR agonists in addition to their pressure lowering effects in the eye, may act directly upon retinal neurons, including retinal ganglion cells. The presence of $\alpha_{2}$-ARs on the RGC-5 cell line allows future investigation of these possible direct effects using in vitro glaucoma model systems.
\end{abstract}

in vivo studies have shown that in addition to lowering intraocular pressure, alpha- $2 \alpha$ adrenergic agonists, such as brimonidine, decrease retinal ganglion cell death subsequent to increases in intraocular pressure, ${ }^{1-4}$ retinal ischaemia, ${ }^{5-8}$ or optic nerve crush. ${ }^{9}$ Alpha-2 agonists, unlike other proposed neuroprotective agents-for example, $\beta$ adrenergic antagonists, are thought to work directly via interaction with their receptor. This has been shown in studies where the protective effect, enabled in the presence of an $\alpha_{2}$ agonist, is reversed or diminished in the presence of an $\alpha_{2}$ selective antagonist, such as yohimbine ${ }^{61011}$ or rauwolscine. $^{56}$

Studies evaluating brimonidine or other $\alpha_{2}$ adrenergic receptor $\left(\alpha_{2}\right.$-AR) agonist effectiveness as neuroprotective agents have used the drug applied either topically $y^{6-8} 1213$ or systemically. ${ }^{1}{ }^{5}$ 7-9 14 These studies do not allow discrimination between whether the drug is acting directly to be neuroprotective, or indirectly by affecting surrounding mediators. These surrounding mediators include the vasculature systemically or locally, inflammatory mediators or other non-retinal ocular tissue such as in the anterior segment. An agent could be directly protective in glaucoma if it interferes with or blocks retinal ganglion cell apoptosis, the terminal outcome in glaucoma, and cause of irreversible loss of corresponding visual fields. A target for a neuroprotective agent in glaucoma would be the retinal ganglion cell, being both the output neuron for the retina and the cell that dies via apoptosis in glaucoma. ${ }^{15-19}$ Such a drug may thus have a direct effect on the cells involved in glaucoma pathogenesis.

There are at least three distinct $\alpha_{2}$-AR subtypes. ${ }^{20}$ The $\alpha_{2 A^{-}}$ $\mathrm{AR}$ is the predominant subtype in the central nervous system and the receptor subtype for which brimonidine has highest affinity. ${ }^{21}$ Despite the knowledge that $\alpha_{2}$ adrenergic agents exert their neuroprotective effect by receptor binding, little is known about the $\alpha_{2}$ adrenergic binding sites within the retina. Table 1 reviews the current published data on localisation of $\alpha_{2}$-ARs to the eye, including knowledge of localisation to the retina. Previous evidence of the intraretinal localisation of $\alpha_{2}$-ARs comes from radioligand binding or autoradiography studies, which have localised $\alpha_{2}$-AR to the mammalian (in particular to the human) retina without intraretinal receptor subtype localisation. Recently, Wheeler et $a l^{3}$ demonstrated that $\alpha_{2}$-ARs were present on rat ganglion cells as well as cells in the inner nuclear layer. Owing to the known difference in tissue expression of $\alpha_{2}$-ARs among different animal species, ${ }^{22-24}$ and the fact that the intraretinal $\alpha_{2}$-AR expression has not yet been shown in humans, we aimed to define the intraretinal localisation of $\alpha_{2}$-AR in the human retina. We also aimed to confirm previous rat intraretinal $\alpha_{2}$-AR localisation. ${ }^{3}$

In addition to human and rat intraretinal localisation, we looked for the presence of specific ganglion cell localisation using a novel retinal ganglion cell line, RGC-5. The RGC-5 cell line is a virally transformed rat retinal ganglion cell line and is currently the only retinal ganglion cell line. ${ }^{25}$ It expresses Thyl-1 and Brn-3c, ganglion cell markers and also various neurotrophin receptors. The $\mathrm{RGC}-5$ line morphologically differentiates with serum deprivation and succinyl concavalin A treatment, and also undergoes excitotoxic apoptosis with glutamate. ${ }^{25}$

\section{MATERIALS AND METHODS}

Preparation of retinas for immunohistochemistry

Seven human postmortem donor eyes (ethics approval HREC 03225) from five different donors were obtained from the Lions Eye bank (Sydney, Australia). Patient age ranged from 26 to 84 years with no significant known ocular conditions besides cataract extractions. Human eyes were pre-fixed in $2 \%$ paraformaldehyde overnight. Retinal trephines were equilibrated in $30 \%$ sucrose, blocked, mounted, frozen, and sectioned onto sialinated coated slides.

A total of three freshly enucleated adult rat eyes (ethics approval ACEC 1997/101) were used for this study and were processed as per human retinas.

Abbreviations: $\alpha_{2}-A R$, alpha- 2 adrenergic receptor; CRALBP, cellular retinaldehyde binding protein; $\mathrm{GCL}$, ganglion cell layer; $\mathbb{I N L}$, inner nuclear layer; ONL, outer nuclear layer; PBS, phosphate buffered saline 
Table 1 Previous studies localising $\alpha 2$ adrenergic receptors to the eye

\begin{tabular}{|c|c|c|c|c|c|}
\hline Species & Tissue & Technique & $\begin{array}{l}\alpha \text { receptor } \\
\text { subclass }\end{array}$ & Alpha adrenergic positive tissues & Reference \\
\hline Human cadaveric & $\begin{array}{l}\text { Whole eye cross } \\
\text { sections }\end{array}$ & $\begin{array}{l}\text { In vitro ligand binding and } \\
\text { autoradiography }\end{array}$ & $\alpha 2$ & $\begin{array}{l}\text { +++ iris and ciliary epithelium } \\
++ \text { ciliary muscle, retina, RPE } \\
\text { (and/or choroid) }\end{array}$ & 26 \\
\hline Rats and rabbits & $\begin{array}{l}\text { Whole eye cross } \\
\text { sections }\end{array}$ & Autoradiography & $\alpha 2$ & $\begin{array}{l}\text { Ciliary processes } \\
\text { Ocular muscles } \\
\text { Retina and RPE }\end{array}$ & 27,28 \\
\hline Human & $\begin{array}{l}\text { Cornea } \\
\text { Ciliary body }\end{array}$ & Immunofluorescence & $\alpha 2 \mathrm{~A}, \alpha 2 \mathrm{~B}, \alpha 2 \mathrm{C}$ & $\begin{array}{l}\alpha 2 \mathrm{~A}, \alpha 2 \mathrm{~B} \text { and } \alpha 2 \mathrm{C} \text { : cornea } \\
\alpha 2 \mathrm{~B} \text { and } \alpha 2 \mathrm{C} \text { : ciliary body }\end{array}$ & 29 \\
\hline \multirow[t]{2}{*}{ Rabbit } & Ciliary body & $\begin{array}{l}\text { Immunofluorescence/ } \\
\text { polymerase } \\
\text { chain reaction/ } \\
\text { dot blot hybridisation }\end{array}$ & $\alpha 2 \mathrm{~A}, \alpha 2 \mathrm{~B}, \alpha 2 \mathrm{C}$ & $\begin{array}{l}\alpha 2 \mathrm{~A} \text { : positive in rabbit ciliary } \\
\text { body by immunofluorescence }\end{array}$ & \\
\hline & & & & $\begin{array}{l}\text { RNA encoding: } \alpha 2 \mathrm{~A}, \alpha 2 \mathrm{~B}, \alpha 2 \mathrm{C} \\
\text { all present in rabbit iris-ciliary body }\end{array}$ & \\
\hline Human and bovine & Retinal homogenates & Radioligand binding & $\alpha$-adrenergic & Retina & $30-33$ \\
\hline Human & $\begin{array}{l}\text { Trabecular meshwork } \\
\text { cells }\end{array}$ & Immunofluorescence & $\alpha 2 \mathrm{~A}, \alpha 2 \mathrm{~B}, \alpha 2 \mathrm{C}$ & $\alpha 2 \mathrm{~A}$ & 34 \\
\hline Human & $\begin{array}{l}\text { Ciliary body } \\
\text { RPE-CC } \\
\text { Iris } \\
\text { Retina }\end{array}$ & Radioligand binding & $\alpha 2 \mathrm{~A}, \alpha 2 \mathrm{~B}, \alpha 2 \mathrm{C}$ & $\begin{array}{l}\alpha 2 \mathrm{~A}: \\
+++ \text { iris } \\
++\mathrm{RPE}-\mathrm{CC} \text { and ciliary body } \\
+ \text { retina }\end{array}$ & 35 \\
\hline Bovine & Retina & Radioligand binding & $\alpha 2 \mathrm{~A}, \alpha 2 \mathrm{~B}, \alpha 2 \mathrm{C}, \alpha 2 \mathrm{D}$ & $\begin{array}{l}\alpha 2 D+++ \\
\alpha 2 A+\end{array}$ & 23,36 \\
\hline Porcine & $\begin{array}{l}\text { Iris } \\
\text { Ciliary body } \\
\text { Choroid } \\
\text { Retina }\end{array}$ & Radioligand binding & $\alpha 2 \mathrm{~A}, \alpha 2 \mathrm{~B}, \alpha 2 \mathrm{C}$ & $\begin{array}{l}\alpha 2 A \text { in iris, ciliary body, and choroid } \\
\alpha 2 A \text { and } \alpha 2 C \text { in retina }\end{array}$ & 24 \\
\hline Rabbit & $\begin{array}{l}\text { Iris-ciliary body } \\
\text { membranes }\end{array}$ & Radioligand binding & $\alpha 1$ and $\alpha 2$ adrenergic & $\begin{array}{l}\alpha 2 \text { subtype in iris-ciliary body } \\
\text { membrane }\end{array}$ & 37 \\
\hline Rabbit & Ciliary body & Radioligand binding & $\alpha 1$ and $\alpha 2$ adrenergic & $\alpha 2$ subtype in ciliary body & 38 \\
\hline & Retina & Radioligand binding & $\alpha 1$ and $\alpha 2$ adrenergic & $\begin{array}{l}\alpha 1 \text { subtype in } \mathrm{OPL} \\
\alpha 2 \text { subtype }++\mathrm{IPL},+\mathbb{N L} \text { and } \mathrm{GCL}\end{array}$ & 39 \\
\hline Rat & Retina & Immunohistochemistry & $\alpha 2 \mathrm{~A}$ & $\alpha 2 \mathrm{~A}$ in the $\mathrm{GCL}$ and $\mathrm{INL}$ & 3 \\
\hline
\end{tabular}

\section{Cell culture and preparation of RGC-5 cells}

The transformed rat retinal ganglion cell line, RGC-5, (gift from $\mathrm{N}$ Agarwal) was grown as previously described ${ }^{40}$ on poly-L-lysine coated glass coverslips. Adherent cells were differentiated as previously described for 3, 5, and 7 days. ${ }^{25}$ Coverslips were fixed in $4 \%$ paraformaldehyde.

\section{Antibodies}

A chicken polyclonal antibody generated to recognise the $\alpha_{2} \mathrm{~A}-\mathrm{AR}^{41}$ was generously supplied by $\mathrm{J}$ Regan. Primary antibody and control normal chicken IgY (R\&D Systems, AB-101-C) were used at a dilution of 1:150. Secondary antibody goat anti-chicken IgG conjugated to alexa 546 (molecular probes, A-11040) was used at a dilution of 1:200. Cell nuclei were identified counterstaining with Hoechst 33258 (molecular probes, H1398).

\section{Immunohistochemistry}

Immunohistochemistry was performed using the indirect antibody method. Briefly, specimens were blocked with 5\% normal goat serum, incubated overnight with primary antibody diluted into $0.4 \%$ saponin for permeabilisation. Following extensive washes with phosphate buffered saline (PBS), the immunoreactivities were revealed by secondary antibody goat anti-chicken conjugated to fluorochrome alexa 546.

Controls included omission of the primary antibody, normal chicken IgY substituted in place of the primary antibody, and staining of human cornea, a known positive control for this $\alpha_{2}$ AR antibody. ${ }^{29}$ Preliminary co-localisation studies were performed by dual incubation with the $\alpha_{2} \mathrm{~A}$-AR antibody along with vimentin (Dako, M0725), cellular retinaldehyde binding protein (CRALBP) (gift from $M$ Maddigan) and appropriate FITC secondary antibodies (Zymed 04-6111 and molecular probes A12373) (data not shown).

\section{Analysis}

Fluorescence was visualised and photographed using a confocal laser microscope (Leica TCS SP) equipped with Leica confocal software (version 2.5) attached to a two photon imaging system (Leica TCS MP). Images were taken with $20 \times$ (HC PL fluotar $20 \times 0.5$ dry, Leica) and $63 \times$ water objectives (HC PL apo $63 \times 1.2$ Wcorr, Leica). Images collected with the $543 \mathrm{~nm}$ excitation laser were pseudocoloured red while those taken with the $790 \mathrm{~nm}$ excitation laser were pseudocoloured blue.

A total of 82 images of human retina stained with $\alpha 2 \mathrm{~A}-\mathrm{AR}$ antibody, 165 human retina negative controls ( 115 secondary only and $50 \mathrm{IgY}$ negative controls), 73 human cornea, 25 of rat retina stained with $\alpha 2 \mathrm{~A}-\mathrm{AR}$ antibody, 34 rat negative controls (29 secondary only and four IgY negative controls). Total number of images stained with $\alpha 2_{\mathrm{A}}$-AR antibody for the RGC- 5 cells were 27 undifferentiated, 9 day three, 6 day five, and 28 day seven differentiated RGC-5 cells. Thirty six negative control images were taken (27 secondary only and 9 IgY negative controls). Intensity of the human tissue staining was graded with - representing no staining; + representing low or weak staining; ++ representing moderate or intermediate staining; and +++ representing high or strong levels of staining. 

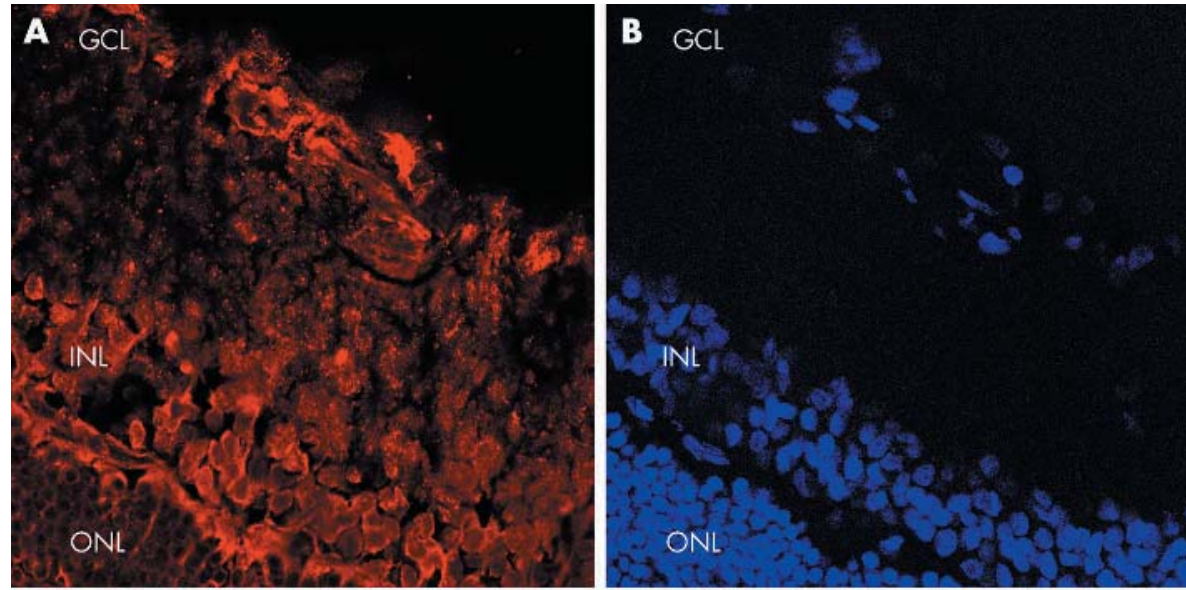

Figure $1 \quad \alpha_{2 A^{-}}$AR expression in the rat retina. Confocal images of rat retina labelled with $\alpha_{2 A}-A R$ antibody

throughout retinal layers. (A) Shows positive immunostaining for the $\alpha_{2 A}$-AR on retinal ganglion cells, cells in the inner nuclear layer (INL) and less so, but also on the membrane of outer nuclear layer (ONL) cells. (C) A retina control with secondary antibody alone showing no non-specific staining. (B) and (D) are equivalent to (A) and (C) retinal sections, respectively, showing Hoechst nuclear counterstaining. All images are taken with the $\times 63$ objective, (C) shows $25 \mu \mathrm{m}$ scale bar. $\mathrm{GCL}$, ganglion cell layer.
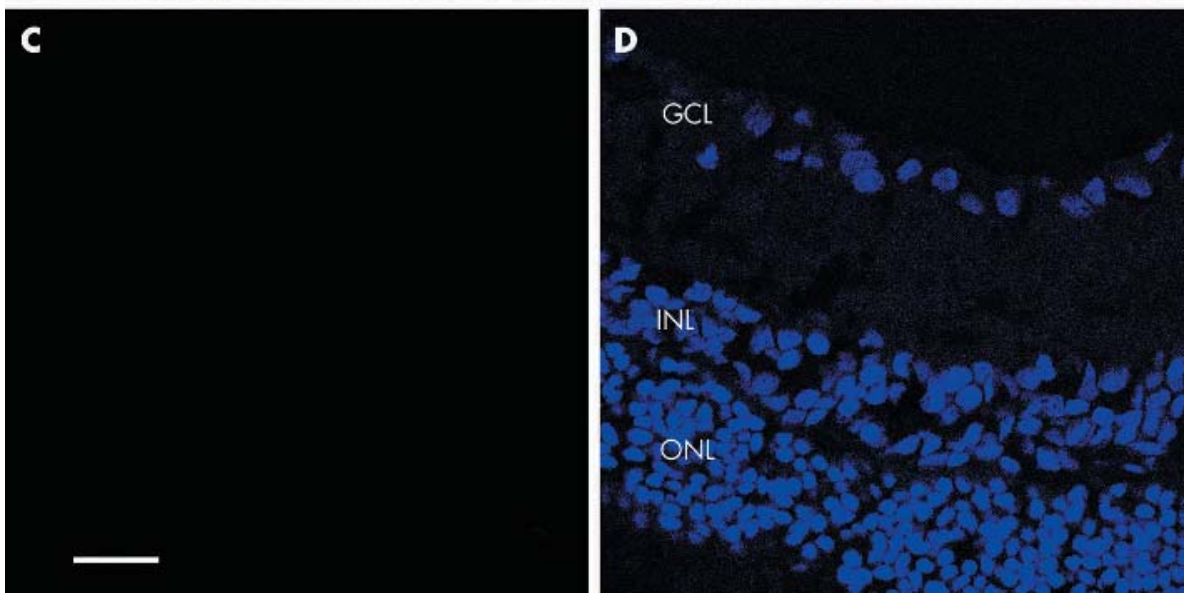

\section{RESULTS}

Strong $\alpha_{2 \mathrm{~A}}$-AR staining was shown in human cornea, a known positive control (fig 2A). ${ }^{29}$ In the rat retina, we confirmed the presence of $\alpha_{2}$-ARs on the somas of the ganglion cells and many of the cells in the inner nuclear layer. The immunopositive labelled cells all displayed uniform staining (fig lA). In the human retina, $\alpha_{2}$-ARs were localised to the soma of ganglion cells, a subpopulation in the inner nuclear layer (INL) and a smaller subpopulation within the outer nuclear layer (ONL) (figs $2 \mathrm{E}$ and G). The intensity of receptor staining varied between layers in the same eye and between similar layers in different eyes, especially in both the INL and ONL as demonstrated by table 2 and figure 2. Within layers, there was variability in the staining levels seen between different eyes as demonstrated by figures $2 \mathrm{E}$ and $\mathrm{G}$, images taken of different eyes. A sample quantitative count was carried out on two eyes using five images, with Hoechst counts defining total cell numbers. The percentage of positive cells staining in the ganglion cell layer was $>80 \%$, INL $40 \%$ and ONL only $20 \%$ positive. Of the positive staining cells in the ONL nearly all were weak + compared to the INL, which was mainly +++ (43\%) and ++ (49\%).

In the RGC-5 cell line, the $\alpha_{2 \mathrm{~A}}$-AR staining was seen on both undifferentiated (fig 3A) and differentiated cells (fig 3B, $\mathrm{C}$, and D); however, staining was more intense on the day 7 differentiated RGC-5 cells (see fig 3D). Differentiated cells (fig 3D) cease to proliferate and display neurites unlike undifferentiated cells (fig 3A).

Preliminary tissue co-localisation studies did not reveal the positive alpha immunostaining to coincide with the staining for CRALBP (a Muller cell marker) ${ }^{42-44}$ or vimentin, ${ }^{42}$ glial cell markers (results not shown).

The antibody was checked for any non-specific binding by incubation of retinas and RGC-5 cells with secondary antibody alone, to test for any non-specific binding of the secondary and with host normal chicken IgY to test for any non-specific binding of our chicken primary antibody. Both negative controls were negative (see figs $\mathrm{IC}, 2 \mathrm{C}$, and $3 \mathrm{E}$ ), indicating no non-specific binding of our antibody for the $\alpha_{2} \mathrm{~A}-\mathrm{AR}$.

\section{DISCUSSION}

This is the first study immunochemically demonstrating the presence of $\alpha_{2}$-ARs on human retinal ganglion cells and other retinal neurons in both the inner and outer human retina. This study also demonstrated the presence of the $\alpha_{2}$-ARs on the RGC-5 cell line.

Our demonstration of $\alpha_{2}$-AR at the protein level in the retina is superior to both RNA and homogenate binding studies, offering increased anatomical resolution and sensitivity. ${ }^{45}$ Previous studies have identified receptor localisation on rat retinal ganglion cells and other rat retinal neurons. ${ }^{3}$ This does not necessarily mean a similar expression in human retina. Specific receptor antibodies allow confirmation of adrenergic receptor subtype distribution as well as the possibility to test various pharmacological agents that interact specifically with these receptors.

Our current study confirmed previous immunochemical studies $^{3}$ showing the presence of $\alpha_{2}$-ARs (specifically $\alpha_{2 A^{-}}$ ARs) on rat retinal ganglion and inner nuclear layer cells (fig 1), with even strong staining on all immunopositive cells. 

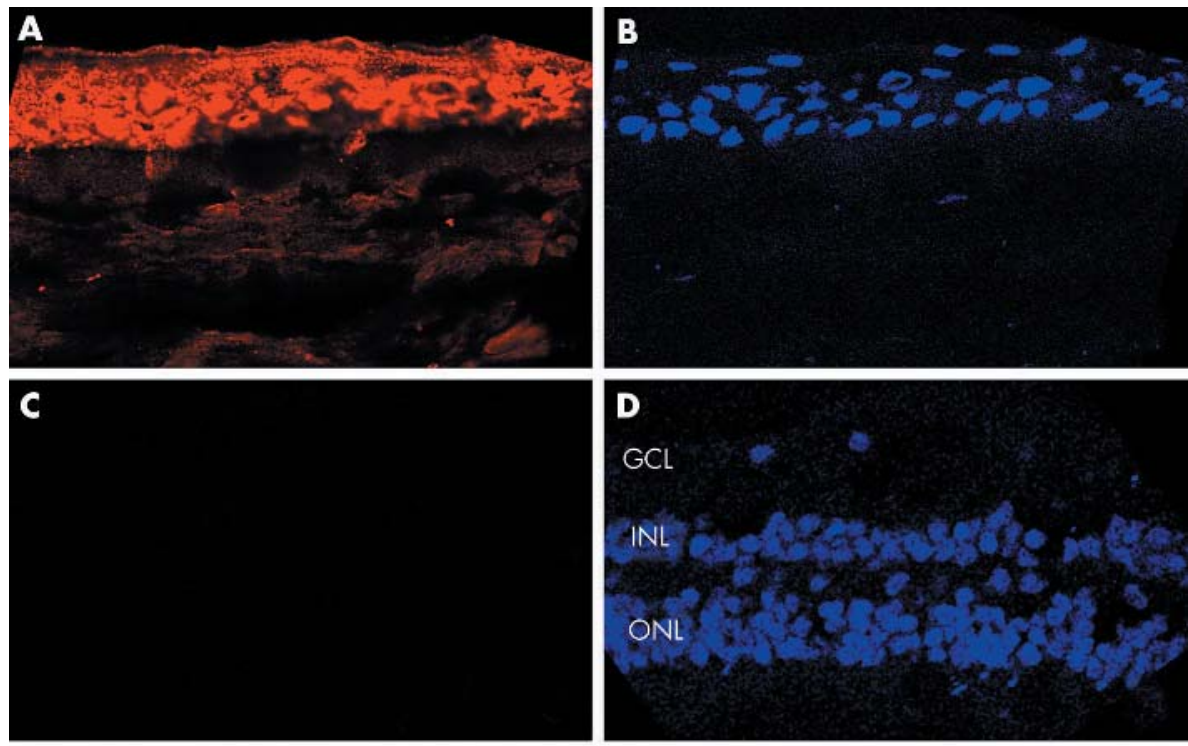

Figure $2 \alpha_{2 A}-A R$ expression in the human cornea and retina. Confocal images of human eye labelled with $\alpha_{2 A^{-}}$ AR antibody in cornea and retinal layers. $(A)$, (E), and (G) Immunostained with $\alpha_{2 A}-A R$ antibody and (C) with chicken $\lg Y$ alone. $(B),(F),(H)$, and (D) Corresponding Hoechst nuclear counterstaining. (A) The positive control, is human corneal epithelium showing specific strong staining for the 2AR. (C) A retina control with chicken IgY alone showing no non-specific staining. (E) and (G) Staining of two different human retinas with positive retinal ganglion cells (arrows) and variable staining in inner (INL) and outer nuclear layers (ONL). Between different retinas, there was some variability in overall intensity but a similar pattern of staining. All images are taken with the $\times 63$ objective. (G) Shows $25 \mu \mathrm{m}$ scale bar. GCL, ganglion cell layer.
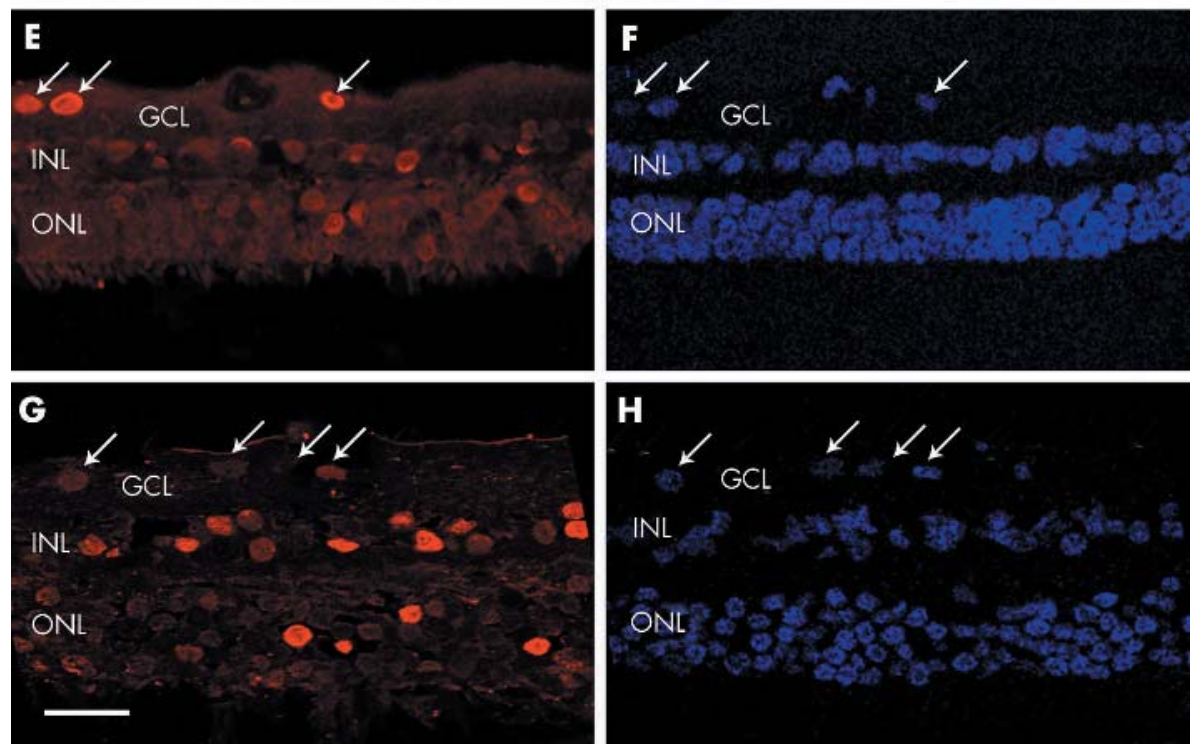

In the human retina we found the presence of $\alpha_{2 \mathrm{~A}}$-ARs on human retinal ganglion cells and retinal cells in the inner and outer nuclear layers. In general, all eyes show a similar overall staining pattern, with some intensity variability

Table 2 Summary of averaged intensity of immunostaining for the $\alpha_{2}$-AR (alpha-2 adrenergic receptor) in the human cornea and retina

\begin{tabular}{lll}
\hline Tissue & Layer & $\boldsymbol{\alpha}_{2}$-AR staining \\
\hline Cornea & Epithelium & +++ \\
Retina & GCL & +++ \\
& INL & 3 populations, many positive \\
& & - \\
& & ++ \\
& ONL & 3 populations, few positive \\
& & - \\
& & + (most) \\
& & $+++($ few $)$ \\
\hline
\end{tabular}

These are the averaged data from all images collected in the current study. Intensity of the human tissue staining was graded, with representing no staining; + representing low or weak staining; ++ representing moderate or intermediate staining; and +++ representing high or strong levels of staining. between eyes (fig 2E and $\mathrm{G}$ ), possibly related to in vivo pharmacological interventions, different ages of eyes, and different time from enucleation to fixation. Differential staining occurred within the inner nuclear layer and outer nuclear layer and could reflect specific neuronal subtypes as these nuclear layers are composed of varying neuronal cell types. Preliminary studies using known glial cell markers, ${ }^{42-44}$ vimentin, and CRALBP did not co-localise with $\alpha_{2 \mathrm{~A}}$ staining, suggesting that immunopositive cells in the inner and outer nuclear layers are neuronal and not glial. Previous studies in other species suggested that the subpopulation of cells staining positively in the inner nuclear layer are amacrine cells. ${ }^{3}$ Studies involving other retinal subclass markers could help to further discern the cell types staining positive for the $\alpha_{2 \mathrm{~A}}$ receptor. The rat retina displays a less apparent differential staining than the human retina without a subpopulation of cells staining positive in the outer nuclear layer, reflecting interspecies variability and confirming the need for this current immunochemical study.

We found markedly enhanced $\alpha_{2 \mathrm{~A}}$-AR expression on day 7 differentiated RGC-5 cells compared to undifferentiated or early differentiated RGC-5 cells (fig 3 ). The changing receptor expression in the RGC-5 cell line with differentiation could reflect changes to in vivo expression levels with neuronal 

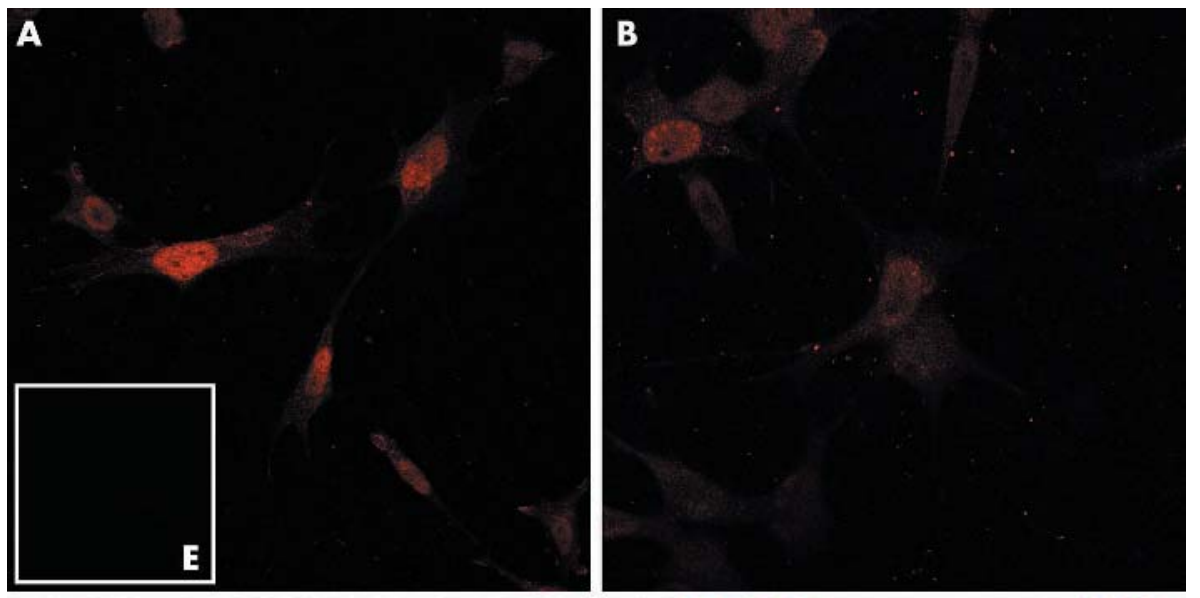

Figure $3 \quad \alpha_{2 A}-A R$ expression in the rat retinal ganglion cell line, RGC-5. Confocal images of rat retinal ganglion cell line RGC-5 labelled with $\alpha_{2 A}-A R$ antibody. (A) Undifferentiated RGC-5 cells have low, though positive, level of $\alpha_{2 A}$-AR expression. (B-D) 3, 5, and 7 days, respectively, of RGC-5 differentiation, showing positive $\alpha_{2 A}$-AR expression, with maximum expression at 7 days of differentiation. (E) (inset) RGC-5 cells with chicken IgY alone showing no non-specific staining. Identical staining and confocal imaging conditions used for all images. All images $\times 40$ objective. (C) Shows $25 \mu \mathrm{m}$ scale bar.
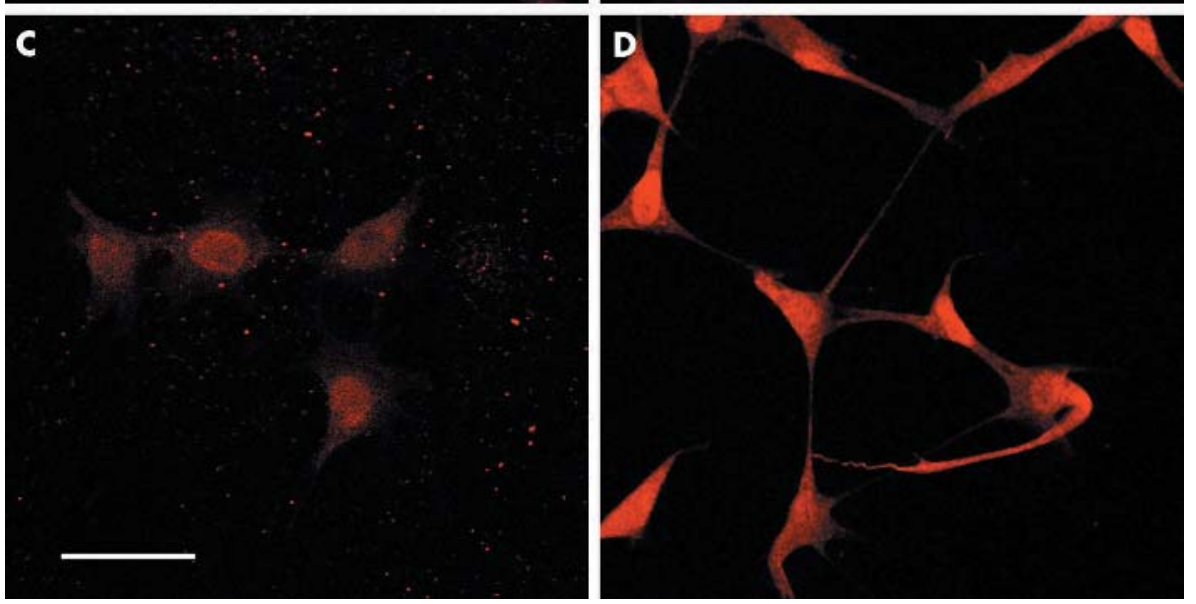

development. The demonstration of $\alpha_{2 \mathrm{~A}}$-ARs on the RGC-5 cells substantiates positive staining found in the ganglion cell layers of human and rat retina, suggesting that positive immunoreactivity in this layer are on the ganglion cells rather than displaced amacrine cells. The presence of $\alpha_{2 \mathrm{~A}}$-ARs on the RGC-5 cell line allows the possibility of studying the direct effect of $\alpha_{2}$-AR agonists on retinal ganglion cells, the target cells of glaucoma. This eliminates the need for studying mixed primary cultures and then using ganglion cell markers in order to identify between the various cell types present. Thus, the direct effect of $\alpha_{2}$-AR agonists can be studied on retinal ganglion cells in culture, while holding relevance to potential human interactions.

Alpha-2 receptor activation has been implicated in enhanced neuronal survival in glaucomatous in vivo mod$\mathrm{els}^{1-9}$ and hence alpha-2 agonists form one of the most studied neuroprotective agents. In contrast with some other proposed neuroprotective agents-for instance, betaxolol, alpha-2 agonists could exert their neuroprotective effect on retinal neurons via direct interaction with their receptor. ${ }^{6} 1011$ Alpha-2-AR stimulation may protect retinal ganglion cells by inhibiting pro-apoptotic mitochondrial signalling, but yet the precise mechanism of neuroprotection is unknown. ${ }^{46}$ Our demonstration of the $\alpha_{2 \mathrm{~A}}-\mathrm{AR}$, the most common subtype of $\alpha_{2}$-ARs found in the central nervous system and the subtype for which brimonidine has highest affinity, ${ }^{21}$ on the human retinal ganglion cell as well as on other retinal neurons, importantly demonstrates a direct target for neuroprotection on and in the vicinity of the ganglion cells, which are dying by apoptosis in glaucoma.

While a direct relation, in neurons, between $\alpha_{2 \mathrm{~A}}$-ARs and apoptosis has not yet been demonstrated, preliminary data from meetings (Wheeler et al, Invest Ophthalmol Vis Sci $2001 ; 42: 411)$ suggest that $\alpha_{2 \mathrm{~A}}$-AR agonists decrease apoptosis through an unknown mechanism that increases Bcl-2 expression. In contrast, the developing embryo expresses $\alpha_{2 \mathrm{~A}^{-}}$ ARs in regions of embryo apoptosis, ${ }^{47}$ suggesting exactly the opposite relation with apoptosis. Further studies using $\alpha_{2 A^{-}}$ ARs agonists and retinal ganglion cells, potentially using the RGC-5 cell line, are required in order to ascertain the relevance of $\alpha_{2}$-ARs in apoptosis and neuroprotection.

\section{ACKNOWLEDGEMENTS}

We thank Professor J Regan for alpha-2A antibody (Department of Pharmacology, University of Arizona, AZ, USA); Associate Professor $\mathrm{N}$ Agarwal for the RGC-5 cell line (Department of Cell Biology and Genetics, University of North Texas Health Science Center, Fort Worth, TX, USA); Dr M Madigan (Save Sight Institute, Sydney, Australia) for technical advice regarding these experiments and for facilitating sufficient ocular tissue for these experiments; and $\mathrm{Mr}$ Paul Halasz for his assistance with the operation of the two photon imaging system.

FBK is a recipient of an NHMRC scholarship.

\section{Authors' affiliations}

F B Kalapesi, M A Hill, Cell Biology Laboratory, Department of Anatomy, School of Medical Sciences, University of New South Wales, Sydney 2052, Australia

M T Coroneo, Department of Ophthalmology, Prince of Wales Hospital, University of New South Wales, Sydney 2052, Australia

Competing interests: The authors have no competing or financial interests.

Ethics approval: University of New South Wales, Human Research Ethics Committee Approval 03225; University of New South Wales, Animal Care and Ethics Committee Approval 1997/101. 


\section{REFERENCES}

1 Ahmed FA, Hegazy K, Chaudhary P, et al. Neuroprotective effect of alpha(2) agonist (brimonidine) on adult rat retinal ganglion cells after increased intraocular pressure. Brain Res 2001;913:133-9.

2 Morrison JC, Nylander KB, Laver AK, et al. Glaucoma drops control intraocular pressure and protect optic nerves in a rat model of glaucoma. Invest Ophthalmol Vis Sci 1998;39:526-31.

3 Wheeler LA, Woldemussie E. Alpha-2 adrenergic receptor agonists are neuroprotective in experimental models of glaucoma. Eur $J$ Ophthalmol 2001;11:S30-35.

4 WoldeMussie E, Ruiz G, Wijono M, et al. Neuroprotection of retinal ganglion cells by brimonidine in rats with laser-induced chronic ocular hypertension. Invest Ophthalmol Vis Sci $2001 ; 42: 2849-55$

5 Donello JE, Padillo EU, Webster ML, et al. Alpha(2)-adrenoceptor agonists inhibit vitreal glutamate and aspartate accumulation and preserve retinal function after transient ischemia. J Pharmacol Exp Ther 2001;296:216-23.

6 Chao HM, Osborne NN. Topically applied clonidine protects the rat retina from ischaemia/reperfusion by stimulating alpha(2)-adrenoceptors and not by an action on imidazoline receptors. Brain Res 2001 ;904:126-36.

7 Vidal-Sanz M, Lafuente MP, Mayor S, et al. Retinal ganglion cell death induced by retinal ischemia. neuroprotective effects of two alpha-2 agonists. Surv Ophthalmol. 2001;45: S261-7; discussion S273-6).

8 Lafuente MP, Villegas-Perez MP, Sobrado-Calvo P, et al. Neuroprotective effects of alpha(2)-selective adrenergic agonists against ischemia-induced retinal ganglion cell death. Invest Ophthalmol Vis Sci 2001;42:2074-84.

9 Yoles E, Wheeler LA, Schwartz M. Alpha2-adrenoreceptor agonists are neuroprotective in a rat model of optic nerve degeneration. [Erratum appears in Invest Ophthalmol Vis Sci 199;40: 2470, ] Invest Ophthalmol Vis Sci, 1999:40:65-73

10 Baptiste DC, Hartwick AT, Jollimore CA, et al. Comparison of the neuroprotective effects of adrenoceptor drugs in retinal cell culture and intact retina. Invest Ophthalmol Vis Sci 2002;43:2666-76.

11 Wen R, Cheng T, Li Y, et al. Alpha 2-adrenergic agonists induce basic fibroblast growth factor expression in photoreceptors in vivo and ameliorate light damage. J Neurosci 1996;16:5986-92

12 Lafuente MP, Villegas-Perez MP, Mayor S, et al. Neuroprotective effects of brimonidine against transient ischemia-induced retinal ganglion cell death: a dose response in vivo study. Exp Eye Res 2002:74:181-9.

13 Vidal-Sanz M, Lafuente MP, Mayor-Torroglosa S, et al. Brimonidine's neuroprotective effects against transient ischaemia-induced retinal ganglion cell death. Eur J Ophthalmol 2001;11:S36-40.

14 Wheeler LA, Gil DW, WoldeMussie E. Role of alpha-2 adrenergic receptors in neuroprotection and glaucoma. Surv Ophthalmol. 2001;45: S290-4; discussion S295-6)

15 Garcia-Valenzuela E, Gorczyca W, Darzynkiewicz Z, et al. Apoptosis in adult retinal ganglion cells after axotomy. J Neurobiol 1994;25:431-8.

16 Garcia-Valenzuela E, Shareef S, Walsh J, et al. Programmed cell death of retinal ganglion cells during experimental glaucoma. Exp Eye Res, 1995, 1995;61:33-44.

17 Kerrigan LA, Zack DJ, Quigley HA, et al. TUNEL-positive ganglion cells in human primary open-angle glaucoma. Arch Ophthalmol 1997;115:1031-5.

18 Quigley HA, Nickells RW, Kerrigan LA, et al. Retinal ganglion cell death in experimental glaucoma and after axotomy occurs by apoptosis. Invest Ophthalmol Vis Sci 1995;36:774-86.

19 Buchi ER. Cell death in the rat retina after a pressure-induced ischaemiareperfusion insult: an electron microscopic study. I. Ganglion cell layer and inner nuclear layer. Exp Eye Res 1992;55:605-13.

20 Lorenz W, Lomasney JW, Collins S, et al. Expression of three alpha 2adrenergic receptor subtypes in rat tissues: implications for alpha 2 receptor classification. Mol Pharmacol 1990;38:599-603.

21 MacDonald E, Kobilka BK, Scheinin M. Gene targeting-homing in on alpha 2-adrenoceptor-subtype function. Trends Pharmacol Sci 1997;18:211-19.

22 Berkowitz DE, Price DT, Bello EA, et al. Localization of messenger RNA for three distinct alpha 2-adrenergic receptor subtypes in human tissues. Evidence for species heterogeneity and implications for human pharmacology. Anesthesiology 1994;81:1235-44.

23 Van Liefde I, Vauquelin G, De Keyser J, et al. Alpha 2A adrenoceptors and non-adrenergic idazoxan binding sites in calf brain and retina are distinct from those in human brain. Neurochem Int 1993;22:501-9.
24 Wikberg-Matsson A, Wikberg JE, Uhlen S. Characterization of alpha 2 adrenoceptor subtypes in the porcine eye: identification of alpha 2Aadrenoceptors in the choroid, ciliary body and iris, and alpha $2 \mathrm{~A}$ - and alpha 2C-adrenoceptors in the retina. Exp Eye Res 1996;63:57-66.

25 Krishnamoorthy RR, Agarwal P, Prasanna G, et al. Characterization of a transformed rat retinal ganglion cell line. Brain Res Mol Brain Res 2001;86:1-12.

26 Matsuo T, Cynader MS. Localization of alpha-2 adrenergic receptors in the human eye. Ophthalmic Res 1992;24:213-19.

27 Lapalus P, Elena PP. Neurotransmitters and intraocular pressure. Fundam Clin Pharmacol 1988;2:305-25.

28 Elena PP, Kosina-Boix M, Denis $P$, et al. Alpha2-adrenergic receptors in rat and rabbit eye: a tritium-sensitive film autoradiography. Ophthalmic Res 1989:21:309-14.

29 Huang Y, Gil DW, Vanscheeuwijck P, et al. Localization of alpha 2adrenergic receptor subtypes in the anterior segment of the human eye with selective antibodies. Invest Ophthalmol Vis Sci 1995;36:2729-39.

30 Borbe HO, Fehske KJ, Muller WE, et al. The demonstration of several neurotransmitter and drug receptors in human retina. Comp Biochem Physiol C Toxicol Pharmacol 1982;72:117-19.

31 Convents A, De Backer JP, Vauquelin G. Characterization of alpha 2adrenergic receptors of calf retina membranes by [3H]-rauwolscine and [3H]RX 781094 binding. Biochem Pharmacol 1987;36:2497-503.

32 Convents A, De Backer JP, Van Driessche E, et al. Glycoprotein nature of alpha 2-adrenergic receptors labeled with p-azido[3H] clonidine in calf retina membranes. FEBS Lett 1988;234:480-4

33 Osborne NN. Binding of $(-)[3 \mathrm{H}]$ noradrenaline to bovine membrane of the retina. Evidence for the existence of alpha 2-receptors. Vis Res 1982;22:1401-7.

34 Stamer WD, Huang Y, Seftor RE, et al. Cultured human trabecular meshwork cells express functional alpha $2 \mathrm{~A}$ adrenergic receptors. Invest Ophthalmol Vis Sci 1996;37:2426-33.

35 Bylund DB, Chacko DM. Characterization of alpha2 adrenergic receptor subtypes in human ocular tissue homogenates. Invest Ophthalmol Vis Sci 1999;40:2299-306

36 Berlie JR, Iversen L, Blaxall HS, et al. Alpha-2 adrenergic receptors in the bovine retina. Presence of only the alpha-2D subtype. Invest Ophthalmol Vis Sci 1995;36:1885-92

37 Mittag TW, Tormay A. Adrenergic receptor subtypes in rabbit iris-ciliary body membranes: classification by radioligand studies. Exp Eye Res 1985;40:239-49

38 Jin Y, Verstappen A, Yorio T. Characterization of alpha 2-adrenoceptor binding sites in rabbit ciliary body membranes. Invest Ophthalmol Vis Sci 1994;35:2500-8

39 Zarbin MA, Wamsley JK, Palacios JM, et al. Autoradiographic localization of high affinity GABA, benzodiazepine, dopaminergic, adrenergic and muscarinic cholinergic receptors in the rat, monkey and human retina. Brain Res 1986:374:75-92

40 Aoun P, Simpkins JW, Agarwal N. Role of PPAR-gamma ligands in neuroprotection against glutamate-induced cytotoxicity in retinal ganglion cells. Invest Ophthalmol Vis Sci 2003;44:2999-3004.

41 Vanscheeuwijck P, Huang Y, Schullery D, et al. Antibodies to a human alpha 2-C10 adrenergic receptor fusion protein confirm the cytoplasmic orientation of the V-VI loop. Biochem Biophys Res Commun 1993;190:340-6.

42 Walcott JC, Provis JM. Muller cells express the neuronal progenitor cell marker nestin in both differentiated and undifferentiated human foetal retina. Clin Exp Ophthalmol 2003;31:246-9.

43 Bunt-Milam AH, Saari JC. Immunocytochemical localization of two retinoidbinding proteins in vertebrate retina. J Cell Biol 1983;97:703-12.

44 Nawrot M, West K, Huang J, et al. Cellular retinaldehyde-binding protein interacts with ERM-binding phosphoprotein 50 in retinal pigment epithelium. Invest Ophthalmol Vis Sci 2004:45:393-401.

45 Kuhar MJ. Receptor localization with the microscope. In: Neurotransmitter receptor binding, In: Yamamura HI, Enna SJ, Kuhar MJ, eds. New York: Raven Press, 1985: 153-76.

46 Wheeler L, WoldeMussie E, Lai R. Role of alpha-2 agonists in neuroprotection. Surv Ophthalmol 2003;48:S47-51.

47 Wang RX, Limbird LE. Distribution of mRNA encoding three alpha 2 adrenergic receptor subtypes in the developing mouse embryo suggests a role for the alpha 2A subtype in apoptosis. Mol Pharmacol 1997;52:1071-80. 